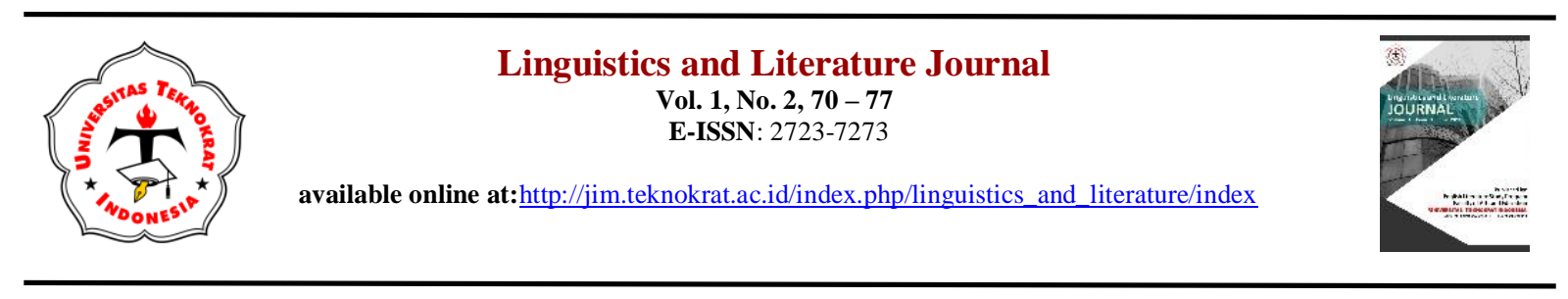

\title{
INTERPERSONAL METADISCOURSE MARKERS IN JACINDA ARDERN SPEECH AT CHRISTCHURCH MEMORIAL
}

\author{
Desma Putri Azijah ${ }^{1}$, Ingatan Gulö ${ }^{2}$ \\ Universitas Teknokrat Indonesia ${ }^{1,2}$
}

desmaputriazijah@gmail.com¹, atan@teknokrat.ac.id ${ }^{2}$

\begin{abstract}
Received: (October 2020)
Accepted: (November 2020)

Published: (December 2020)

Abstract

The research aims to find the types of interactive and interactional metadiscourse markers in Jacinda Ardern's speech at Christchurch memorial, and the function of each metadiscourse markers found in the speech. In doing the analysis, the writers applied Hyland's (2005) framework of interpersonal metadiscourse. This research applied descriptive qualitative method in analyzing and presenting the results. The findings show that Jacinda Ardern used both interactive and interactional resources of interpersonal metadiscourse. She used the interpersonal metadiscourse markers based on its functions. By the use of metadiscourse markers in the speech, Jacainda Ardern has successfully delivered a wellorganized and persuasive speech, and built a good relationship with her audience.
\end{abstract}

Keywords: Christchurch memorial, interactional metadiscourse, interactive metadiscourse, interpersonal metadiscourse, speech

\section{INTRODUCTION}

As one of the latest theories in discourse studies, metadiscourse is a widely used term in current discourse analysis (Hyland, 2010). It is used as to manage social relationship between writer and reader(s). Metadiscourse was described as the interpersonal resources which are used to organize a discourse towards its content or the reader (Hyland, 2015). Metadiscourse studies mostly focus on written texts (Istiani \& Puspita, 2020). However, metadiscourse is a part of spoken text as well (Ädel, 2006). Spoken texts are any piece of spoken language, including interview, speech, conversation, debate and many others. Speech is a process of speaking to a group of people to convey statements, ideas, persuade or entertain the people.

In delivering a speech, a speaker must be aware of several things such as the choice of words, language use and the organization of the speech. "Language is not simply used to convey information about the world. It also acts to present this information through the organization of the text itself' (Hyland, 2005:8). A speaker uses language to negotiate with hearers and to present a text interactively; hence, a speaker can create a relationship with hearer. Furthermore, interpersonal metadiscourse has an important mean in facilitating communication between the text, authors and audience (Esmer, 2017) and understanding implicit meaning of a speaker's utterances is needed in any kind of communications including speech (Fitri \& Qodriani, 2016). Therefore, metadiscourse has an important role in a speech in order to persuade audience. Accordingly, it is considered important to reveal how metadiscourse markers are used in a speech. Thus, the authors in this research are interested in analyzing Jacinda Ardern's speech at Christchurch memorial. As cited from The Washington Post that, people over the world are praising Jacinda Ardern for her response to terrorist attack. The speech lasts about seven minutes which discussed about the terrorist attack and shows Ardern strong solidarity to all New Zealanders and all Muslim community. Through the speech, Ardern has shown, by mourning with people, respect and solidarity, as well as her empathy that make things getting better. The speech made people consider her as an inspirational leader. It can be seen from people's comments on the speech that support and praise her as a leader.

Several studies have discussed the use of metadiscourse markers in spoken texts such as Yipei and Lingling (2013) who investigated the interpersonal and textual meaning of Steve Job's speech in terms of Hyland's (2005) framework. The findings indicate that by the use of metadiscourse in the speech, Steve Jobs has elaborately projected his ideas, supported his position and facilitated mutual communication. Esmer (2017) analyzed the use of interpersonal metadiscourse by Pro-Turkish and Pro-Kurdish Leaders in their election rally speeches and discovered the role of metadiscourse markers in the speeches in the reflection of speakers' 
ideologies. The researcher found that the two political leaders used the same interpersonal metadiscourse in their speeches. However, the markers functioned differently due to the different ideologies of each leader. Tashi and Suksawas (2018) discovered the interactional metadiscourse used in the Prime Minister of Bhutan speeches of various topics and the difference on metadiscourse markers used in every speech. The findings show that the interactional metadiscourse used by the Prime Minister of Bhutan are connected with his audience in an interactive, clear and elaborated direction.

This present study is aimed at analyzing the use of interpersonal metadiscourse markers and the functions of each metadiscourse marker used in Jacinda Ardern's speech at Christchurch memorial. This study is expected to give an overview of interpersonal metadiscourse markers especially how they are used and how they function.

The researchers employed Hyland's (2005) framework of interpersonal model of metadiscourse to do the analysis. The term metadiscourse has been viewed as one of linguistic features that is truly useful and helpful in the field of writing. Kuswoyo and Siregar (2019) have added that metadiscourse is considered as one of the manifest tools used in speaking skills. The concept of metadiscourse is based on Halliday's classification of three metafunctions of language. It is stated that ideational function is fulfilled by primary discourse while interpersonal and textual functions are fulfilled by metadiscourse (Kopple, 1985 in Nasiri, 2013). Varieties of taxonomies of metadiscourse have been proposed by some scholars in which the first taxonomy was proposed in 1985 by Kopple (Duruk, 2017) with textual and interpersonal metadiscourse as the two major categories of metadiscourse. However, metadiscourse can be analyzed from different perspective because it is considered as an open-ended category (Vashegani, 2018). Therefore, different classifications of metaiscourse have been proposed by other scholars. Hyland's proposed that all metadiscourse markers are categorized as interpersonal metadiscourse. All metadiscourse classifications are basically interpersonal because they need to consider the knowledge of the readers, textual experiences and processing needs (Hyland, 2005). Hyland also proposed two major categories of interpersonal metadiscourse by adopting Thompson's (2001) label of interactive and interactional. The explanation will be described below.

\section{INTERACTIVE METADISCOURSE}

Interactive metadiscourse deals with how authors compose the text to influence the readability of the reading and the readers can understand the text flowing. This category refers to the author's awareness of participating audiences and how he seeks to accommodate the possibility of knowledge, interests, rhetorical expectations, and processing abilities. According to Hyland (2005), the resources used in this category discuss ways of organizing discourse, not experience, and express the extent to which the text is built with the reader's needs in mind. Therefore, the author's purpose here is to shape and limit the text to meet the needs of certain readers, establish arguments so that they will restore interpretations and goals that the author likes. This metadiscourse also shows how the writer guides the reader in understanding the text with the aim that the reader is interested and responsive in the text. Interactive metadiscourse which concerns about the writer's awareness are divided into five subcategories.

\section{A. Transitions}

Transitions mainly conjunctions and adverbial phrases which help audiences in indicating relationship between arguments (Hyland, 2005). Transition used to signal additive (and, in addition, furthermore, by the way, etc.), comparison as either similar (similarly, likewise, in the same way, etc.) or different (but, on the other hand, by contrast, however, on the contrary, etc.) and to signal consequence (in conclusion, therefore, thus, the result is, etc.).

\section{B. Frame Markers}

Frame markers are references to signal text boundaries (Hyland, 2005). It can be used to sequence text (first, next, then, for instance, listing $a, b, c, d$, etc.). Frame markers can also be used to label text stages (in sum, in short, by of introduction, etc.) or to announce discourse goals (focus, I want to, I argue that, my purpose is, etc) lastly, frame markers can function to indicate topic shift (OK, well, move on, right, etc.).

\section{Endophoric Markers}

Endophoric markers are expressions that refer to other part of the text (Hyland, 2005). Items included as endophoric markers are as mentioned before, see chapter 1, in chapter three, as noted above, in this section, etc.

\section{Evidentials}

Evidentials indicate an idea from another source which originates outside the current text (Hyland, 2005). Keywords of evidentials which mark the idea of another source outside the text such as according to X, as stated by $X$, mentioned by $X$, etc. 


\section{E. Code Glosses}

Code glosses are the restatement which supplies additional information, by explaining, rephrasing or elaborating what have been stated in the text previously. According to Hyland (2005), code glosses are used to make sure that the audiences are able to recover the author's intended meaning. Markers included as code glosses are for example, in other words, known as, namely, say, that is, etc. in some cases, especially in written text, code glosses can alternatively marked off by parentheses.

\section{INTERACTIONAL METADISCOURSE}

Interactional metadiscourse involves the author's intervention in providing explanations related to information provided in a text. It shows the way the author of a text interacts by commenting on their messages. The author's purpose here is to make his views explicit as well as to engage with readers by enabling them to respond to the text. "It reveals the extent to which the author works to jointly build the text with readers" (Hyland, 2005:50).

\section{A. Hedges}

Hedges are devices such as about, possible, might, almost, feel, perhaps, etc. which indicate the author's reluctance in presenting information in the text (Hyland, 2005). Hedges are used to show that the information presented in a text is based on the author's opinion rather than a fact or certain knowledge.

\section{B. Boosters}

Boosters are devices which express the author's certainty in presenting information (Hyland, 2005). Boosters are devices such as: believe, in fact, certainly, obviously, actually, clearly, etc.

\section{Attitude Markers}

Another subcategory of interactional metadiscourse is attitude markers which indicate the author's attitude to propositions, conveying agreement, surprise, frustration, and so on. It is signaled by devices such as: hopefully, interesting, unexpectedly, etc.

\section{Engagement Markers}

Engagement markers are devices that address audiences. There are two functions of engagement markers (Hyland, 2005). First, to focus audiences' attention which mainly performed by devices such as: see, such as, not, have to, must, etc. Second, to include them as discourse participants in the text with pronouns such: as you, your, inclusive we, us, our, ours, let us.

\section{E. Self-Mentions}

The last subcategory of interactional metadiscourse is self mentions which express the author's presence in the text in terms of first person pronouns and possessive adjective such as: I, my, me, mine, exclusive we, us, our, the author, the writer, the author's.

\section{METHOD}

This study is designed as descriptive qualitative research in which this method design expects to fit with the aim of this study. In addition, Hyland and Jiang (2019) mentioned in their study that analyzing metadiscourse is not simply counting items, rather it involves identifying items. Thus, qualitative method is implemented in analysis of discourse. This study is a qualitative research because in collecting the data, the researcher will examine document, it is supported by Stake (2010), that examining artifacts (including documents) is one of the most common methods used in qualitative research. Moreover, in descriptive qualitative research, the researcher described the results of the analysis in the form of words (Kuswoyo \& Susardi, 2016). This is in line with the aims of this study in which the result of this study will be described in the form of words. In this research, the researchers examined document to collect data. As stated by Creswell (2014), in qualitative, the researcher is the key instrument in which they collect data themselves through examining documents, observing behavior, or interviewing participants. The data in this research are in the form of words, phrases and sentences that can be categorized as metadiscourse markers. The source of the data in this research is the transcript of Jacinda Ardern's speech taken from an online website, The Guardian. 


\section{FINDINGS AND DISCUSSION}

This research analyzed the use of interpersonal metadisscourse markers in Jacinda Ardern's speech at Christchurch memorial. The findings present the interpersonal metadiscourse markers used in Jacinda Ardern's speech as well as the most frequent metadiscourse markers in the speech. These findings are the result of analyzing the data which taken from Ardern's speech. The following table shows the percentage of interpersonal metadiscourse markers used in the speech.

Table 1 Interpersonal Metadiscourse Markers in Ardern's Speech

\begin{tabular}{|c|c|c|}
\hline Subcategory & Number & Percentage \\
\hline Transitions & 30 & 22.22 \\
\hline Frame Markers & 9 & 6.67 \\
\hline Endophoric Markers & - & - \\
\hline Evidentials & 4 & 2.96 \\
\hline Code Glosses & 9 & 6.67 \\
\hline Total Interactive resources & $\mathbf{5 2}$ & $\mathbf{3 8 . 5 2}$ \\
\hline Hedges & 8 & 5.93 \\
\hline Boosters & 12 & 8.89 \\
\hline Attitude Markers & 3 & 2.22 \\
\hline Engagement Markers & 45 & 33.33 \\
\hline Self Mentions & 15 & 11.11 \\
\hline Total Interactional resources & $\mathbf{8 3}$ & $\mathbf{6 1 . 4 8}$ \\
\hline Total Interpersonal Metadiscourse & $\mathbf{1 3 5}$ & $\mathbf{1 0 0}$ \\
\hline
\end{tabular}

As seen in the above table, 135 interpersonal metadiscourse markers are found in the speech, 52 or $39.4 \%$ of them are the interactive metadiscourse markers and the other $61.48 \%$ or 83 markers are included as the interactional metadiscourse markers. The use of interpersonal metadiscourse in the speech shows that the speaker tries to help her audiences in understanding the idea of the speech by organizing her speech using interactive metadiscourse, and to build interaction with the listeners through the use of interactional metadiscourse markers in her speech. The results show that the use of interactional metadiscourse markers is more dominant than the interactive metadiscourse markers. It is in line with the finding of previous study conducted by Yipei and Lingling (2013), in which the researchers also found that the interactional metadiscourse markers are used more frequently than the interactive metadiscourse markers, and also no endophoric markers are found in the speech. More than half of interpersonal metadiscourse markers in spoken texts are the interactional resoures.

Transitions have an important role in organizing a text, especially in written text. To add, transitions are the fundamental linguistics elements in writing (Agustinos, Arsyad \& Syahrial, 2018). However, transitions markers are also used in spoken text to organize the text structure. It is proven by the occurrence of transition markers in Jacinda Ardern's speech at Christchurch memorial as the dominant category amongst other interactive metadiscourse markers used in the speech. It is in line with the result of previous study conducted by Yipei and Lingling (2013) in which the researchers found out transition markers used more frequently than other interactive markers.

\section{Excerpt 1}

And we also ask that the condemnation of violence and terrorism turns now to a collective response. (Speech at Christchurch memorial, 2019).

The words "and" and "also" in the sentence above can be included in and function as interpersonal metadiscourse markers and as interactive resources in transitions category (Hyland, 2005). The marker functions as additive. In addition to thanking everyone who has joined the Christchurch Memorial, the speaker also added statement which asked that violence and terrorism turn to a collective response. The conjunction "and" here functions as a connector with the speaker's pervious statement. The use of transitions "and" together with "also" in a sentence suggests that it is not merely used to add information. Jacinda Ardern also shows her attitude in her statement, signaling the importance of the information given. Another example of transition "and" can be seen in excerpt 2 .

\section{Excerpt 2}

But even when we had no words, we still heard yours, and they have left us humbled and they have left us united. (Speech at Christchurch memorial, 2019). 
There are two transitions in the example. The use of "and" in the sentence is to indicate additional information. In excerpt 2, Jacinda Ardern talks about words spoken by the victims and the victims' families of the terrorist attack, even in a situation in which other people had no words to say such words that can express what they feel about the terrorist attack. A collection of words can be included as either an English sentence or a clause when consists of at least a subject and a verb (Afrianto \& Inayati, 2016). The use of the first and the second "and" in the sentence signals semantic relations between clauses. It functions to add additional information. Ardern told the audiences that even when they do not know what to say to the victims' and their families, they can still hear those words spoken by the victims and their families in that kind of situation. In the speech, Jacinda Ardern used transition "and" to add that those words made them humbled. The second "and" used in the sentence also functions to add additional information in the argument. Ardern used the markers to add that the words also made everyone who hear the words feel that they are united. The main function of frame markers is to signal text boundaries (Hyland, 2005). In Jacinda Ardern's speech at Christchurch memorial, the researcher found that she also used frame markers. The example can be seen in excerpt 3 .

\section{Excerpt 3}

Over the past two weeks we have heard the stories of those impacted by this terrorist attack. They were stories of bravery. They were stories of those who were born here, grew up here, or who had made New Zealand their home. Who had sought refuge, or sought a better life for themselves or their families. (Speech at Christchurch memorial, 2019).

Jacinda Ardern uses the frame marker to sequence the text. By using the frame marker, Jacinda Ardern clearly express topic that she is going to discuss about what have they heard in the past two weeks that is the story about the terrorist attack from everyone who have been impacted by the terrorist action. The speaker used the phrase "over the past two weeks" to signal text boundaries. Referring to Hyland (2005), frame markers signal text boundaries including items used to sequence the text. Therefore, the phrase "over the past two weeks" can be categorized as frame marker. Evidential is a subcategory of interactive metadiscourse markers which refer to a source from outside the current text (Hyland, 2005). Below is the example of sentences containing evidential.

\section{Excerpt 4}

They were simple words, repeated by community leaders who witnessed the loss of their friends and loved ones. Simple words, whispered by the injured from their hospital beds. Simple words, spoken by the bereaved and everyone I met who has been affected by this attack. (Speech at Christchurch memorial, 2019).

Evidential in the excerpt 4 are noun phrases such as: repeated by, whispered by and spoken by. Previously, Jacinda Ardern tells about words that she heard, and then she gives the sources from which she heard those words. All evidential used in the speech have the same function that is to refer to the source of information which originally outside the text. Jacinda used different phrases to mark the sources of those simple words she heard, to indicate that she heard those simple words not only from one source. She heard those simple words from different sources: the community leaders and the victims of the terrorist attack. In her speech, Jacinda used evidentials repeatedly to help her audiences understand that she heard those words from more than one source. According to Hyland (2005), evidentials may contribute to a persuasive goal. By the use of this metadiscourse marker, Jacinda Ardern has successfully persuaded the people by giving the source of the informations. Most importantly, evidential are being used to appeal textual support. Code glosses used in Jacinda Ardern's speech function to mark the speaker's elaboration to supply additional information. The example of it can be seen in excerpt 5 .

\section{Excerpt 5}

But with that memory comes a responsibility. A responsibility to be the place that we wish to be. A place that is diverse, that is welcoming, that is kind and compassionate. Those values represent the very best of us. (Speech at Christchurch memorial, 2019).

Code glosses in the sentence are expressed by the use of words "that is". The speaker used those words to elaborate what she means in her pervious statement that is about a place that they wish to be. The wish that the speaker means in her speech is diverse, welcoming, kind and compassionate place. The use of code gloss in the speech reflects Jacinda Ardern's prediction about her audience knowledge. Those markers also emphasize the speaker's intended meaning of her previous statement. Code glosses are used to ensure that the listeners can understand the speaker's intended meaning in the text (Hyland, 2005). If the speaker did not use words "that is" or did not use any code glosses in the speech, the composition of the text will not be good and the audiences may not be understand about what the speaker mean in her speech.

Hedges are the first subcategory of interactional metadiscourse markers. According to Hyland (2005), hedges are used to express the author's reluctance in presenting an argument. The researcher found words that 
can be recognized as hedges in the speech. Based on the researcher's point of view, Jacinda Ardern's main purpose in delivering the speech here is to show her solidarity and her empathy to her audiences. And to convince that to the people, the speaker did not use a lot of hedges in her speech, because using too much hedges in a text will affect persuasiveness of the text itself. The use of hedges in the speech does not mean that the speaker is not sure about what she said. It functions more likely to present an argument as an open discussion, which allowing the audiences to negotiate in the argument. The example of the use of it can be seen in excerpt 6 .

\section{Excerpt 6}

We may have left flowers, performed the haka, sung songs or simply embraced. But even when we had no words, we still heard yours, and they have left us humbled and they have left us united. (Speech at Christchurch memorial, 2019).

The hedge "may" in the sentence above indicates that the speaker provides her own opinion rather than information from certain knowledge. If Jacinda Ardern did not use that hedge in the sentence, it will influence the meaning of the statement. By using "may" in her statement, the speaker is allowing her audiences to negotiate in the statement. The sentence in excerpt 6 expresses the probability that the speaker thinks about what will be done by them, including the audiences, to express their empathy. And it is possible that not all of the people did what she said in her statement. Therefore, the hedge "may" is needed in the sentence. The use of hedges and boosters also shows that Ardern has tried to build interaction with his audience. The example of boosters used in her speech can be seen in excerpt 7.

\section{Excerpt 7}

Because we are not immune to the viruses of hate, of fear, of other. We never have been. But we can be the nation that discovers the cure. (Speech at Christchurch memorial, 2019).

The use of "never" in the sentence above shows the speaker's certainty in giving a statement or information. Previously, the speaker said that everyone is not immune to the viruses of hate and others. And then the speaker added her statement that indicates her certainty and her confidence in providing her opinion in the statement. The use of the hedge "never" in the sentence emphasizes the speaker's confidence in providing a statement to the audience. She emphasizes her own opinion that no one never been immune to such kind of viruses.

Attitude markers express the speaker's attitude towards propositional information. "Instead of commenting on the status of information, its probable relevance, reliability or truth, attitude markers convey surprise, agreement, importance, obligation, frustration and so on" (Hyland, 2005:53). The markers used to express Jacinda Ardern's attitude in her speech. See the example of it in excerpt 8.

\section{Excerpt 8}

To the global community who have joined us today, who reached out to embrace New Zealand, and our Muslim community, to all of those who have gathered here today, we say thank you. (Speech at Christchurch memorial, 2019).

The phrase "thank you" expresses the speaker's value as a modest speaker. In her speech, Jacinda does not forget to thank everyone who has come to the event and to all people who have joined the event. She thanks to everyone for their contribution. As a leader of a country, Jacinda Ardern does not forget to show her respect for other people. So, by the use of that attitude marker, Jacinda has shown her respect and her value as a modest speaker for the people who involved in the speech by thanking them all.

Self mentions show the author presence in a text. According to Hyland (2005:53), "Writers cannot avoid projecting an impression of themselves and how they stand in relation to their arguments, their community and their reader." Self mention is usually express by the use of first-person pronoun and possessive adjective. The use of self mentions also can show the speaker's affirmation as well as help the speaker to prove her reliability from the audiences. The example of self mentions in the speech can be seen in the following excerpt.

\section{Excerpt 9}

I thought there were none. And then I came here and was met with this simple greeting. (Speech at Christchurch memorial, 2019).

The first person pronoun "I" in the excerpt above can be recognized as self mentions. Self mentions in the sentence above highlighted Jacinda Ardern's presence in presenting the statement. The first person pronoun "I" explicitly refer to the author of the text as well as shows her position as the speaker in the text. In addition, Jacinda also uses exclusive we such as: we, our and us in her speech which functioned as self mentions as well. The example of it can be seen below. 


\section{Excerpt 10}

To the global community who have joined us today, who reached out to embrace New Zealand, and our Muslim community, to all of those who have gathered here today, we say thank you. (Speech at Christchurch memorial, 2019).

In the sentence above, pronoun "we" is an explicit reference to the speaker in the speech and her team. The pronoun "we" in the sentence does not refer to the audiences, hence it can be categorized as self mentions. The use of "us" and "our" in the sentences above also have the same reference as the pronoun "we" in the above sentence. According to Hyland (2005), self mentions are expressed by the use of first person pronouns and possessive adjectives. Therefore, those words are included as self mentions. Self mentions used in the speech are to show the speaker's self-affirmation to her audiences. Moreover, self mentions can also be used to draw audiences' attention. By the use of self mention in those sentences, Jacinda Ardern has drawn her audiences' attention to focus on her statements.

Engagement markers are included as interactional metadiscourse markers. Engagement markers are devices that address audiences. Engagement markers are the dominant interactional metadiscourse markers found in Jacinda Ardern's speech. Based on the above table, pronouns are used the most. As discussed previously that there are two functions of the use of engagement markers; hence, in this study, the researcher will discussed which engagement markers function to focus the audiences' attention and which are used to include the audiences as discourse participants. See excerpt 19 below.

\section{Excerpt 11}

And we also ask that the condemnation of violence and terrorism turns now to a collective response. (Speech at Christchurch memorial, 2019)

The underlined word in excerpt 11 can be recognized as engagement marker. The use of that word in the sentence is functioned to focus audiences' attention. By using the word "turns" in the above sentence, Jacinda Ardern wanted to focus the audience's attention on what she had to say. In that sentence, Jacinda said that violence is now a collective response. Another example of the use of engagement markers in the speech can be seen in excerpt 12 .

\section{Excerpt 12}

And so to each of us as we go from here, we have work to do, but do not leave the job of combatting hate to the government alone. (Speech at Christchurch memorial, 2019)

The underlined words above also have a function to focus the audiences' attention. The words "do not" is used by speaker to emphasize to the audiences that the job of combating hate is not the job of the government only. The use of that marker marks that Jacinda Arderns wants to emphasize to her audience to remember that everyone's role is indispensable in fighting hatred. And cooperation between the government and the citizens is urgently needed to fight them.

\section{CONCLUSION}

After analyzing the data, both interactive and interactional metadiscourse markers were found the speech. There are 52 interactive metadiscourse markers and 83 interactional metadiscourse markers used by the speaker in her speech. It is concluded that the number of interactional resources found in the speech is more than the interactive resources. This can be recognized as one of the differences between the use of interpersonal metadiscourse markers in spoken text and written text in which written text mostly used interactive metadiscourse more than the interactional metadiscourse markers. Transitions become the most frequent markers among other interactive metadiscourse in the speech. Jacinda Ardern has successfully produced a well-organized text by using transition markers in her speech. The use of transition markers gives clear transition between steps in the speech. Most of transitions markers found in the speech function to add additional information; however there is also transition which functions to mark difference. The functions of frame markers found in the speech are to order arguments and to sequence the text. In addition, the use of evidential markers and code glosses in the speech has successfully created a coherent speech. This research found that engagement markers are the dominant markers among other interactional metadiscourse markers used in the speech. Forty five of 83 interactional resources are recognized as engagement markers. This may be in line with Jacinda Ardern's goal in delivering her speech that is to urge all audiences to always show solidarity and respect for others. With engagement markers, Jacinda Ardern has succeeded in building relationships and interaction with the audiences by inviting them into her text. The speaker also used self mentions to show her presence in the text and to engage with her audiences. The use of hedges, boosters and attitude markers make the speech becomes persuasive. 


\section{REFERENCES}

Ädel, A. (2006). Metadiscourse in L1 and L2 English. Amsterdam: John Benjamins.

Afrianto \& Inayati, A. (2016). Excitential process in Harry Potter and the Chamber of Secret: a systemic functional linguistic study. Teknosastik: Jurnal Bahasa dan Sastra, 14(1), 26-31.

Agustinos, P., Arsyad, S., \& Syahrial. (2018). Metadiscourse markers in the undergraduate thesis introduction written by English department students in University of Bengkulu. Journal of English Education and Teaching 2(3), 50-61.

Creswell, J. W. (2014). Research Design: Qualitative, Quantitative, and Mixed Methods Approaches (4 ${ }^{\text {th }}$ ed). United States: SAGE Publications Inc.

Duruk, E. (2017). Analysis of metadiscourse markers in academic written discourse produced by Turkish researchers. Journal of Language and Linguistics Studies, 13(1), 1-9.

Esmer, E. (2017). Interpersonal metadiscourse markers in Turkish election rally speeches delivered by proTurkish and pro-Kurdish leaders. Athens Journal of Social Sciences, 4(4), 367-384.

Fitri, E., \& Qodriani, L. U. (2016). A study on flouting maxims in Divergent novel. Teknosastik: Jurnal Bahasa dan Sastra, 14(1), 32-40.

Hyland, K. (2005). Metadiscourse: Exploring Interaction in Writing. London: Continuum.

Hyland, K. (2010). Metadiscourse: Mapping interactions in academic writing. Nordic journal of English Studies. Special Issue on Metadiscourse, 9(2), 125-143.

Hyland, K. (2015). Metadiscourse. In Tracy, K. (ed.) International Encyclopaedia of Language and Social Interaction. Oxford: Wiley-Blackwell.

Hyland, K., \& Jiand, K. (2019). Text-organizing metadiscoourse: tracking changes in rhetorical persuasion. Journal of Historical Pragmatics 20(1).

Istiani, R., \& Puspita, Dian. (2020). Interactional metadisocurse used in Bloomberg international debate. Linguistics and Literature Journal, 1(1), 13-20.

Kuswoyo, H., \& Siregar, R. A. (2019). Interpersonal metadiscourse markers as persuasive strategies in oral business presentation. Lingua Cultura, 13(4), 297-304.

Kuswoyo, H., \& Susardi. (2016). Thematic progression in EFL students' academic writing: a systemic functional grammar study. Teknosastik: Jurnal Bahasa dan Sastra, 14(2), 39-45.

Nasiri, Sina. (2013). Exploring the significant role of meta-discourse in academic writing for a discourse community by academicmembers. International Journal of Research Studies in Education, 2(1), 67-74.

Stake, R, E. (2010). Qualitative Research Studying How Things Work. New York: The Guilford Press.

Tashi, T., \& Suksawas, W. (2018). An analysis of interactional metadiscourse in public speaking: A case study in English speeches of the prime minister of Bhutan. International Journal of Engineering \& Technology, 7(4.38), 975-979.

Vashegani, F, M. (2018). The usage and distributional pattern of metadiscourse features in research articles in applied linguistics based on Hyland's classification. Applied Linguistics Research Journal, 2(1), 35-51.

Yipei, N., \& Lingling, L. (2013). Investigating interpersonal and textual meaning of Steve Jobs' Stanford speech in terms of Hyland's metadiscourse theory. International Journal of Language and Linguistics, $1(4), 90-96$. 